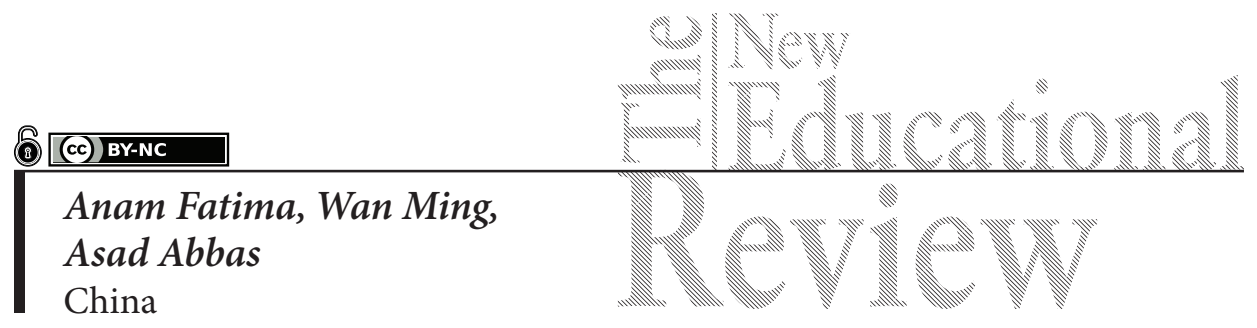

\title{
Chinese Students' Perception on Plagiarism: a Case of Anhui, China
}

DOI: $10.15804 /$ tner.2018.53.3.08

\begin{abstract}
Anhui is one of the leading knowledge-based regions of China, which relies on academic research innovation. This publication aims to present the factors that influence of plagiarism on Chinese students and also explores the common perceptions of students themselves on the idea and act of plagiarism in higher level education environments. The literature provided identifies two major facets of plagiarism, which are both internal and external factors. Qualitative evidence from students demonstrates that both internal and external factors encourage Chinese students to plagiarize during their studies due to the availability of the internet (ICT and Web), lack of teaching expertise, poor academic skills, pressure from family members and peer groups, and financial constraints. It was also found that personal pride played a significant role in catalyzing the decision to plagiarize. On the basis of the said literature and qualitative evidence, the authors provide relevant recommendations about overcoming the concerns of students regarding plagiarism at the university level.
\end{abstract}

Keywords: academic dishonesty, China, plagiarism, public sector universities, student perception.

\section{Introduction}

Anhui is located in the center of China and is renowned as one of the leading provinces due to its academic research innovation activities. Currently, 59 research 
institutes and public sector universities are operating throughout the Anhui province and most of them are located in Hefei city (Abbas, Avdic, Xiaobao, Hasan, \& Ming, 2018). Research trends also demonstrate that the Anhui province is bringing innovation through its public sector universities. The results of academic innovation (as a solution) are transferred from individuals or research groups of universities to local industries according to government-given intellectual property rights, policies, and laws. The purpose is to encourage university-industry collaboration for industrial innovative product development. The University of Science and Technology of China (USTC) is one of the top ten public sector universities in China and it is also ranked 98 in the world. Along with the USTC, there are other well-reputed public sector universities such as Anhui University, Anhui Agricultural University, Anhui Medical University, and Hefei University of Technology, all of which are located in the Anhui province (ARWU-Shanghai, 2018; Quacquarelli, 2018). These aforementioned universities are renowned within the province and also throughout China. This is partly due to the large number of academic contributions these universities maintain and develop, usually in the form of local and international research publications. The quality of education and the large number of local and international enrolled students are also factors that contribute to their ranking. These elements place Anhui among the top five knowledge-based regions in China and within the last five years, its $10.5 \%$ growth in GDP brought Hefei to the $12^{\text {th }}$ position among the top 20 rapidly growing cities around the world (Abbas, Avdic, Barker, \& Xiaobao, 2018; Hefei-China, 2018).

\section{Discussion Questions}

1. What are the most common influence factors which encourage students to plagiarize in their research studies?

2. What is students' common perception of plagiarism?

3. How can plagiarism as an issue be overcome among students and also at the university level?

\section{Influence Factors of Plagiarism among Chinese Students}

Plagiarism is considered an illegal and unethical behavior or act within the field of research (Shahabuddin, 2009). Some of the latest published studies related to plagiarism demonstrate that it is one of the most rapidly emerging issues in the field of higher education. The term plagiarism is commonly used in the field of education, especially where students and faculty members plagiarize in their 
research work. There are several factors that influence plagiarism and they have emerged in the literature with a focus on students, faculty, administrative members (Vehviläinen, Löfström, \& Nevgi, 2018), and their individual acts or behaviors.

For a better understanding of the factors that influence plagiarism, we have divided the Šprajc, Urh, Jerebic, Trivan, and Jereb (2017) concept of plagiarism into two different categories, i.e., internal and external factors. Internal factors related to plagiarism are based on academic skills, pressure, and pride, whereas external factors depend on Information and Communication Technology (ICT) and Web (known as the internet), ideas about control, and teaching factors (Jereb, Urh, Jerebic, \& Šprajc, 2017; Šprajc, Urh, Jerebic, Trivan, \& Jereb, 2017).

Published work that is available online shows that the behavior of specific genders (male or female) is commonly found as a victim of plagiarism (Quraishi \& Aziz, 2017). During their time of study at the university level, students often face internal factors which are hard to control such as academic skills, pressure, and pride. Students have said that higher education can, in fact, help them as students to enhance and build on their intellectual, interpersonal, and academic skills for a successful career without actively engaging in any academic dishonesty. Other sub-factors such as pressure from family, peers, and financial issues also have an influence on studies. Pride, however, is one of the main reasons for plagiarism. It comes about when students plagiarize because of their fear of failure, low score or grades, and because of a small amount of time given to complete their academic task.

\section{Chinese Students Perceptions on Plagiarism}

Qualitative evidence was collected from university students about their perception on plagiarism related to their study level (such as Bachelor's, Master's, and $\mathrm{PhD}$ program) and type of enrolment (such as full and part-time). According to the arguments of university students, full time and higher study level students are well aware of university rules and regulation and also international research ethics policies due to their published research work in reputed journals. This is in stark comparison to earlier level university students (such as Bachelor's students), who do not have academic research experience, poor academic skills, and who are unaware of university research and ethical rules and regulations. This encourages them to plagiarize during the course of their academic career and amidst their research work assignments.

Because part-time students maintain their studies along with their jobs, they do not pay full attention to their studies. In the majority of Chinese universities, the 
study requirements for part-time students are not as strict compared to full-time students. Due to this, part-time students do not hesitate in plagiarizing their work in order to complete assigned tasks. In fact, they actually perceive that this act of plagiarism can be forgiven.

Students believe that control of plagiarism can only be achieved at school or at the faculty level. The university cannot control or stop plagiarism without eliminating the internal motivation of plagiarism. It includes internal ideologies, self-beliefs and personal morality of the individual student themselves, all of which help them avoid any act of plagiarism and, of course, its consequences. Some public sector university teachers lack teaching expertise or research skills, which can have an effect on students and inadvertently encourage them to engage in plagiarism during their course work.

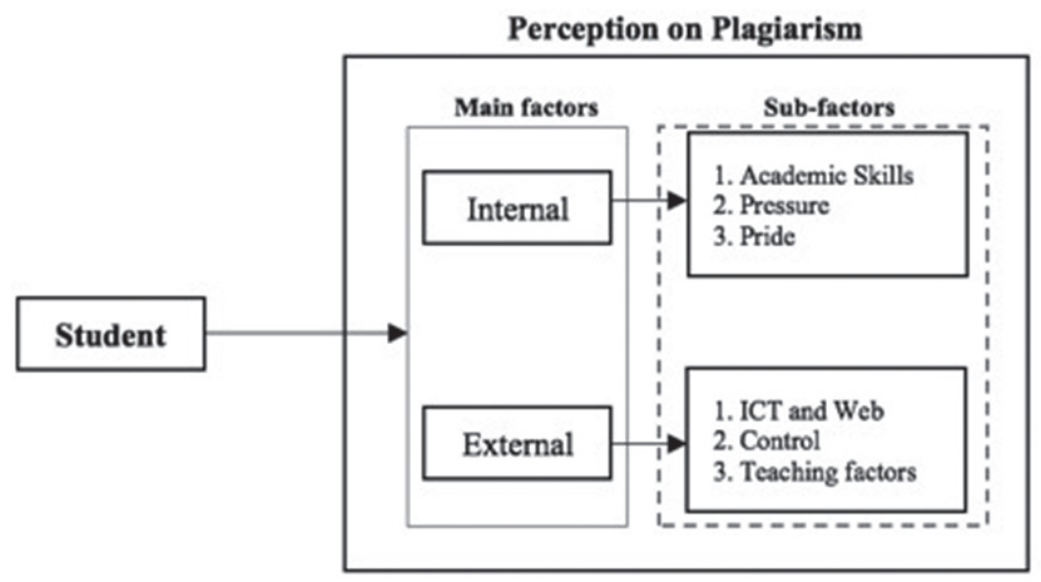

Figure 1. Students' perception on plagiarism (Conceptual model)

\section{Conclusion and Recommendations}

On the basis of the collected evidence about student perception on plagiarism, we have proposed some recommendations to overcome plagiarism issues at the university level:

- This research will help Chinese public sector universities to encourage possible reforms in their existing academic ethics policies according to 
international and national academic ethical guidelines such as the Committee on Publication Ethics (COPE).

- University administrative departments should design training workshops and seminars for faculty members that will raise awareness of the seriousness of plagiarism, the use of plagiarism checking software, and possible punishments.

- At the time of student enrollment, university faculty and administrative members should arrange seminars at the department level about academic ethics and should also assess penalties (in the case of academic dishonesty or plagiarism) such as expulsion from school or university, etc.

- The university should implement the latest plagiarism checking software (both local and international) to control plagiarism in students' course work and research project assignments in order to improve the quality of academic research.

- Establishment of a quality control department such as Quality Enhancement Cell (QEC) within the university will help ensure that the university ethical rules and regulation are enforced and applied, so that they can avoid any plagiarism activity at the university level.

- The government (local and central) should allocate more funding to public sector universities to improve their existing structure for promoting quality education.

- Common rules for both full-time and part-time students should be established, for them to obey university academic ethics.

- The financial departments of universities must propose and start financial support programs for needy students at the school and university levels. This will help students to overcome any family pressure and any financial issues. Research groups of departments and university can also start some financial awards geared to the students, on the basis of their course work performance and research work achievements. The research groups of departments and universities can encourage students to publish quality work and get some sort of reward.

\section{Teaching Note}

\section{Case Synopsis}

This case study focuses on the university students and their perceptions on plagiarism issues in their research studies. The selected five public sector universities are from the Anhui province, which is one of the leading academic research 
and innovation regions, which is located in the center of China. Rapid research and development trends related to academic research innovation encourage us to explore the students' perceptions on plagiarism in their research studies. Innovative research results and quality of education are the main source of quality university graduates, which helps local industries to get more benefit from regional educational research institutes or universities related to industrial solution and training programs.

\section{Target Audience}

As a target group for this case study, we considered only Chinese students who are currently enrolled and studying in public sector universities. We used published literature to identify plagiarism factors and also to support our arguments. The observation of each individual was transferred as a written note on notepad. This helped us to draw conclusions on the basis of collected qualitative evidence related to perceptions on plagiarism in studies. We also give some recommendations to overcome highlighted plagiarism issues at the study level in the Chinese public sector university context.

\section{Objective of the Case Study}

The objective of this case study is to explore the key influence factors and common perceptions of Anhui-based Chinese public sector university students on plagiarism. The discussion on this emerging research topic will help both Chinese and international researchers to get a better understanding of the common perception of academic dishonesty or integrity within Chinese universities. Our research study discusses and highlights some of the most important factors that influence university students to engage in plagiarism during their research studies.

\section{Acknowledgements}

The first author (Anam Fatima) would like to express gratitude to the China Scholarship Council (CSC) for awarding Master's scholarship at the University of Science and Technology of China (USTC).

\section{References}

Abbas, A., Avdic, A., Barker, K.C., \& Xiaobao, P. (2018). Knowledge transfer from universities to industry through university technology transfer offices. Science and Innovation, 14(2), 05-18. doi:10.15407/scine14.02.005. 
Abbas, A., Avdic, A., Xiaobao, P., Hasan, M. M., \& Ming, W. (2018). University-government collaboration for the generation and commercialization of new knowledge for use in industry. Journal of Innovation \& Knowledge. doi:10.1016/j.jik.2018.03.002.

ARWU-Shanghai. (2018). Best Chinese universities ranking - Overall ranking 2017 Retrieved from http://www.shanghairanking.com/Chinese_Universities_Rankings/ Overall-Ranking-2017_1.html

Hefei-China. (2018). Hefei overview. Retrieved from http://www.hefei.gov.cn/english/23177/overview/200510/t20051025_1396929.html

Jereb, E., Urh, M., Jerebic, J., \& Šprajc, P. (2017). Gender differences and the awareness of plagiarism in higher education. Social Psychology of Education, 1-18. doi:10.1007/ s11218-017-9421-y.

Quacquarelli. (2018). Top Universities. Retrieved from https://www.topuniversities.com/ universities/university-science-technology-china

Quraishi, U., \& Aziz, F. (2017). Academic dishonesty at the higher education level in Punjab, Pakistan. Journal of Research \& Reflections in Education, 11(1), 68-85.

Shahabuddin, S. (2009). Plagiarism in academia. International Journal of Teaching and Learning in Higher Education, 21(3), 353-359.

Šprajc, P., Urh, M., Jerebic, J., Trivan, D., \& Jereb, E. (2017). Reasons for plagiarism in higher education. Organizacija, 50(1), 33-45. doi:10.1515/orga-2017-0002.

Vehviläinen, S., Löfström, E., \& Nevgi, A. (2018). Dealing with plagiarism in the academic community: Emotional engagement and moral distress. Higher Education, 75(1), 1-18. doi:10.1007/s10734-017-0112-6. 